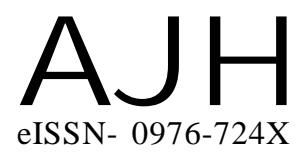

Article history :

Received : 10.04.2016

Revised : 27.04.2016

Accepted : 06.05.2016

Author for Correspondence :

YOGESH SINGH

Department of Horticulture, C.C.S.

Haryana Agricultural University,

HISAR (HARYANA) INDIA
THEASIAN JOURNALOF HORTICULTURE

Volume 11 | Issue 1 | June, 2016 | 136-140

Visit us -www.researchjournal.co.in
RESEARCH PAPER

DOI : 10.15740/HAS/TAJH/11.1/136-140

\section{Effects of Rhizobacteria strains in prolonging vase life of gladiolus cv. AMERICAN BEAUTY}

\section{YOGESH SINGH}

ABSTRACT : Gladiolus is one of the popular cut flowers that demonstrates postharvest problems which cause shorter vase life and loss of quality. The present study was undertaken to compare the efficiency of different rhizobactera strains application on vase life of gladiolus. A significant improvement was observed in all the parameters related to vase life with the application of Azotobacter, Azospirillium, Bacillus and Pseudomonas strains as biofertilizers. Maximum vase life 18.22 days was observed under $\mathrm{T}_{7}$ (Pseudomonas sp. CPS20), which was at par with $\mathrm{T}_{6}$ (Pseudomonas sp. CPS63) i.e. 18.17 days. The maximum spike weight $(73.67 \mathrm{~g}$ ) was noticed under $\mathrm{T}_{1}$ (Azotobacter chroococcum Mac27) and highest transpirational loss was recorded on 8th day of vase life (27.33 g) whereas, minimum under control on $2^{\text {nd }}$ day of vase life $(9.67 \mathrm{~g})$. Wilting of floret was delayed by 4.56 days under Pseudomonas sp. CPS20. Among all the vase solutions of biofertilizers, Pseudomonas sp. CPS20 was found to be the most effective, followed by Pseudomonas sp. CPS63 for improving vase life of cut spikes of gladiolus.

KEY WORDS : Gladiolus, Biofertilizer, Rhizobacteria, Vase life, Spike, Floret

HOW TO CITE THIS ARTICLE : Singh, Yogesh (2016). Effects of Rhizobacteria strains in prolonging vase life of gladiolus cv. AMERICAN BEAUTY. Asian J. Hort., 11(1) : 136-140, DOI : 10.15740/HAS/ TAJH/11.1/136-140. 